\title{
Analisis Kepemimpinan Manajerial Kepala Sekolah Terkait Peningkatan Budaya Prestasi Sekolah Di MTs. Kota Bima
}

\author{
Sri Haryanti \\ email: haryatisri355@gmail.com \\ Dosen pada STAI Al-Amin Dompu
}

\begin{abstract}
Abstrak: Peran Kepala sekolah sebagai manajer mempunyai posisi penting dalam meningkatkan kualitas sekolah. atas dasar itu, penelitian difokuskan pada kepemimpinan kepala sekolah dalam meningkatkan prestasi di sekolah. penelitian ini menggunakan pendekatan deskriptif kualitatif, yang dilakukan di MTSN I Kota Bima dan MTS Muhammadiyah Kota Bima.

Teknik pengumpulan data yang digunakan meliputi: (1) wawancara mendalam dengan kepala sekolah, guru, wakil kepala sekolah, siswa, kementerian agama dan komite; (2) observasi untuk mendapatkan gambaran tentang keadaan sekolah, pada saat kepala sekolah melakukan rapat dan melakukan pembinaan terhadap guru-guru, dan observasi terhadap kegiatan siswah; dan (3) dokumentasi dipilih berdasarkan teknik purposive sampling dan di padukan dengan snowball sampling. data yang terkumpul di sekolah di analisis melalui tahap reduksi data, display data dan penarikan kesimpulan, dan untuk mengecek Kebenaran data di analisis dengan mengunakan triangulasi sumber dan metode. Hasil penelitian sebagai berikut: (1) terdapat perbedaan kepemimpinan kedua sekolah sehingga memiliki budaya prestasi yang berbeda; (2) bentuk pembinaan siswa yang dilakukan oleh kedua sekolah berbeda, MTSN I melakukan pembinaan kepada siswa tidak hanya saat mengikuti lomba saja tetapi diadakan setiap minggunya, namun. Hal tersebut berbanding terbalik dengan yang terjadi di MTS Muhammadiyah Kota Bima. Sehingga menyebabkan prestasi kedua sekolah tersebut berbeda.
\end{abstract}

Kata kunci: Kepemimpinan, Manajerial, Kepala Sekolah

\section{Pendahuluan}

Era persaingan global semakin ketat untuk menghadapi tantangan global, pemerintah terus berupaya dalam meningkatan mutu pendidikan dengan mengamanatkan secara tersurat melalui UU No. 20 tahun 2003 pasal 51 yang menyatakan bahwa setiap lembaga pendidikan wajib menyelenggarakan manajemen berbasis sekolah (MBS) dalam rangka memenuhi standar pelayanan minimal (SPM). Standar pelayanan minimal wajib dipenuhi oleh setiap Kabupaten/Kota sekurang-kurangnya dalam waktu 3 tahun setelah SPM tersebut dikeluarkan (Renstra Permendikbud, 
2015-2019; Permendikbud Nomor 23 Tahun 2013). Penjaminan mutu pendidikan yang dilakukan oleh pemerintah dimaksudkan agar setiap satuan pendidikan berusaha memenuhi standar pelayanan minimal (Minarti, 2011). Standar ini dijadikan sebagai alat untuk meningkatkan mutu secara merata dan terfokus (Usaid Kinerja, 2014). Pemerataan mutu pendidikan bertujuan untuk membangun tercapainya budaya mutu bagi pendidikan formal, nonformal dan informal (Permendiknas No 63 Tahun 2009).

Kemajuan pendidikan di Indonesia secara kuantitas cukup mengembirakan namun secara kualitas, perkembanganya masih belum merata. Berdasarkan hasil penelitian bahwa belum meratanya pendidikan di Indonesia, disebabkan oleh potensi dan kemampuan sekolah yang berbeda serta kurangnya kemampuan manajerial para pimpinan pendidikan, sehingga mutu pendidikan yang dihasilkan bervariasi (Andang, 2014; Dally, 2010). Fakta lapangan menunjukan bahwa variasi mutu pendidikan juga terjadi di Kota Bima dari 10 sekolah MTSN dan swasta namun hanya satu sekolah MTSN yang terakreditasi A. Sementara enam sekolah MTS lainya baik negeri maupun swasta masih terakreditasi B dan C bahkan tiga sekolah MTS masih belum terakreditasi (Kemenag, 2016). Kelemahan mutu dari komponenkomponen pendidikan berujung pada rendahnya kualitas manajerial pimpinan pendidikan (Saondi, 2014). Sekolah sebagai satuan pendidikan tidak akan menjadi bermutu baik dan unggul, jika tidak dikelola oleh kepala sekolah melalui manajemen yang tepat.

Melihat permasalahan diatas maka peneliti akan mengambil sekolah yang terakreditasi A dan B yang ada di Kota Bima untuk melihat konstribusi yang diberikan oleh Kepala Sekolah terhadap pencapaian keberhasilan sekolah. Penelitian ini difokuskan pada kepemimpinan manajerial kepala sekolah terkait peningkatan budaya prestasi sekolah di Tsanawiyah Negeri dan Swasta yang ada di Kota Bima. Oleh karena itu, peneliti ingin mengetahui: (1) bagaimana kepemimpinan manajerial Kepala Sekolah dalam meningkatkan budaya prestasi sekolah?; (2) apa faktor pendukung Kepala Sekolah sebagai manajerial dalam meningkatkan budaya prestasi di sekolah?; (3) apa kendala yang dihadapi Kepala Sekolah sebagai manajerial dalam meningkatkan budaya prestasi di Sekolah?; (4) bagaimana upaya yang dilakukan oleh kepala sekolah sebagai manajerial dalam mengembangkan budaya prestasi di sekolah?.

\section{Kepemimpinan Kepala Sekolah}

Menurut Mulyasa (2012) Kepala Sekolah merupakan pemimpin dalam suatu sekolah yang bertanggung jawab, terhadap maju mundurnya sekolah yang dipimpinya. Sementara menurut Rahman (2006), Kepala Sekolah merupakan tenaga fungsional guru yang menduduki jabatan struktural yang diberi tugas tambahan untuk memimpin sekolah. Berdasarkan pengertian diatas maka dapat disimpulkan bahwa kepala sekolah adalah orang yang diberi tugas tambahan untuk memimpin sekolah dan bertanggung jawab terhadap maju mundurnya sekolah.

Menurut Permendiknas No 28 tahun 2010 tentang penugasan guru untuk menjadi Kepala Sekolah dikatakan bahwa Kepala Sekolah adalah guru 
yang diberi tugas tambahan karena sudah memenuhi persyaratan umum dan persyaratan khusus. Hal ini senada dengan yang disampaikan oleh Subandono (2011) bahwa untuk dapat menjadi Kepala Sekolah, seseorang harus memenuhi persyaratan-persyaratan yang meliputi kemampuan untuk menguasai keterampilan profesional dan kompetensi administrasi, serta mampu melakukan kepengawasan terhadap komponen yang ada. Menurut (Mulyasa, 2012; Wahyosumidjo, 2002; Rahman, 2006) Persyaratanpersyaratan yang perlu dikuasai oleh kepala sekolah sebagai pemimpin diantaranya adalah:

a. Keahlian atau kemampuan dasar seperti mempunyai kecakapan spesifik seperti proses, prosedur, dan teknik-teknik yang digunakan untuk menganalisis hal-hal yang khusus serta mempunyai keterampilan untuk bekerja sama dengan orang lain sebagai anggota kelompok;

b. Kualifikasi pribadi seperti memiliki mental yang unggul, emosi yang stabil, dan berwatak sosial serta memiliki sikap empati dan loyal terhadap semua komponen yang ada di sekolah.

Kepala sekolah sebagai pemimpin dituntut untuk bisa menguasai semua kompetensi, hal ini sebagaimana yang telah diatur oleh Permendiknas No 13 Tahun 2007 tentang standar kepala sekolah yang meliputi: (1) kompetensi kepribadian; (2) manajerial; (3) kewirausahaan; (4) supervisi; (5) kompetensi sosial. Merujuk kepada lima peran kepala sekolah di atas, dapat diuraikan secara ringkas hubungan antara kepala sekolah dengan peningkatan prestasi sekolah adalah sebagai berikut:

(1) kompetensi kepribadian merupakan kemampuan untuk selalu konsisten dalam berfikir, bersikap, dan berucap; (2) kepala sekolah sebagai manager pendidikan harus mampu untuk mendorong keterlibatan seluruh komponen sekolah dalam berbagai kegiatan untuk menunjang program sekolah; (3) kewirausahan maka kepala sekolah seharusnya dapat menciptakan pembaharuan, keunggulan komparatif, serta memanfaatkan berbagai peluang. (4). kepala sekolah sebagai supervisor. harus mampu melakukan supervisi terhadap pekerjaan yang dilakukan oleh tenaga kependidiknya; (5) kompetensi sosial merupakan kemampuan untuk berinteraksi dan berkomunikasi dengan orang lain dalam menjalin kerja sama baik secara induvidual maupun kelompok.

Kompleksnya penguasaan keterampilan yang harus dimiliki oleh kepala sekolah menunjukan bahwa pekerjaan ini bukanlah pekerjaan yang mudah.

\section{Tipe Kepemimpinan Kepala Sekolah}

Keberhasilan organisasi sebagian besar sangat ditentukan oleh kepemimpinan lembaga tersebut. Tipe kepemimpinan identik dengan gaya kepemimpinan seseorang. Menurut (Siagian, 2003) tipe kepemimpinan kepala sekolah dapat dibagi menjadi lima tipe pokok adalah sebagai berikut:

a. Tipe kepemimpinan otokratis

Tipe kepemimpinan ini menempatkan kekuasaan pada satu orang sebagai penguasa tunggal, sementara kedudukan bawahan hanya sebagai pelaksana keputusan, pemimpin memandang dirinya lebih dari segalanya 
dan bawahan tunduk pada kekuasaan sang pemimpin. kekuasaan pemimpin di gunakan untuk menekan bawahanya, dengan mempergunakan sanksi sebagai hukuman atau alat utama.

Tipe kepemimpinan otokratis memiliki ciri antara lain: (1) beban kerja organisasi pada umumnya ditanggung oleh pemimpin; (2) konsep atau ide berasal dari pemimpin; (3) disiplin tinggi, bekerja keras dan tidak mengenal lelah; (4) kebijakan ditentukan oleh pemimpin, kalaupun ada rapat sifatnya hanya sebatas pemberitahuan/sosialisasi; (5) tidak adanya kepercayaan pemimpin kepada bawahanya (Mulyadi, 2010).

b. Tipe kepemimpinan paternalistik

Tipe ini sangat mengutamakan kebersamaan dan memperlakukan semua bawahanya dengan adil dan sama rata. Tipe kepemimpinan ini biasanya (1) menganggap bahwa bawahan sebagai manusia yang belum dewasa; (2) mereka bersikap terlalu melindungi; (3) jarang memberikan kesempatan kepada para bawahanya untuk mengambil keputusan (4) merasa paling benar dan mengetahui segalanya.

c. Tipe kepemimpinan kharismatik

Tipe kepemimpinan ini mempunyai kemampuan dalam menggerakkan dan memberdayakan orang yang dipimpinya dengan akhlak yang terpuji, sehingga menimbulkan rasa hormat, segan, dan patuh terhadap pimpinanya. Tipe kepemimpinan ini membawa daya tarik yang luar biasa sehingga mempunyai banyak pengikut dan pengawal-pengawal yang dapat dipercaya. Kepemimpinan ini dianggap sebagai kemampuan yang supernatural yang diperoleh dari karunia yang maha kuasa.

d. Tipe kepemimpinan bebas (laissez faire)

Tipe kepemimpinan ini memberikan kebebasan penuh kepada orang yang dipimpinya untuk melakukan kegiatan menurut kehendak dan kepentingnya masing-masing. Pemimpin hanya memposisikan dirinya sebagai penasehat, dalam kepemimpinan ini jika tidak ada anggota yang mengambil inisiatif untuk menetapkan keputusan maka kegiatan organisasi tidak ada. Tipe kepemimpinan ini tidak efektif karena seorang pemimpin terlalu banyak memberikan kebebasan kepada para pengikutnya, untuk menentukan aktivitas mereka sehingga organisasi ini menjadi kacau karena pemimpin tidak mampu menciptakan suasana kerja yang kooperatif.

e. Tipe kepemimpinan demokratis

Tipe kepemimpinan ini memberikan kesempatan yang luas kepada anggota organisasi untuk berpartisipasi aktif dalam setiap kegiatan. Pembagiaan tugas kerja kepada para anggota disertai dengan pelimpahan wewenan dan tanggung jawab. Pelimpahan wewenang dan tanggung jawab yang jelas memungkinkan anggota berpartisipasi secara aktif.

Tipe kepemimpinan yang dipaparkan oleh para ahli dibidang pendidikan semuanya hampir sama, hanya saja ada beberapa bagian yang berbeda diantanya seperti tipe Kepemimpinan pseudo-demokratik yang di jelaskan oleh (Munir, 2008) Kepemimpinan ini seakan-akan berlangsung secara demokratik karena pemimpin berusaha bersikap dan bertingkah laku baik kepada semua bawahanya dengan memberikan hak dan kekuasaan kepada bawahanyan untuk memutuskan sesuatu, tetapi sesungguhnya 
pemimpin ini bekerja dengan penuh perhitungan ia mengatur siasat agar nanti keinginanya terwujud. Sementara tipe kepemimpinan yang di jelaskan oleh (Mulyadi, 2010) menambahkan tipe militeristik adalah tipe pemimpin yang memiliki sikap yang selalu menggerakkan bawahanya dengan sistem perintah. Pemimpin menerapkan kedisiplinan yang tinggi namun kaku dari bawahan serta sukar menerima kritikan.

\section{Kepala Sekolah Sebagai Manajer}

Menurut Andang (2014) manajemen adalah proses pengaturan dan pengelolaan yang melibatkan unsur-unsur perencanaan, pengorganisasian, pengalaman dan pengendalian sumber daya yang ada. Menurut (Mulyasa, 2002) manajemen adalah proses yang khas yang terdiri dari tindakantindakan perencanaan, pengorganisasian, dan pengendalian untuk mencapai tujuan yang telah ditentukan melalui pemanfaatan sumber daya manusia dan sumber daya lainya. Berdasarkan pengertian tersebut, dapat diambil kesimpulan bahwa manajemen merupakan ilmu untuk mengatur pemanfaatan sumber daya, baik itu sumber daya manusia maupun sumber daya bukan manusia yang dilakukan melalui perencanaan, pengorganisasian, dan pengendalian untuk mencapai tujuan yang diinginkan.

\section{Fungsi Manajemen Kepala Sekolah}

Peraturan Menteri Pendidikan Nasional Nomor 13 Tahun 2007 tentang standar Kepala Sekolah/Madrasah, disebutkan bahwa seseorang yang menjabat sebagai Kepala Sekolah harus mempunyai lima kemampuan dasar satu diantaranya adalah kemampuan manajerial. Kemampuan ini sangat penting untuk mendorong Kepala Sekolah dalam menjabarkan sumber daya sekolah yang mendukung terlaksananya proses belajar mengajar, serta melakukan perencanaan, pengaturan, pengorganisasian dan memimpin keseluruhan pelaksanaan tugas-tugas pendidikan di sekolah (Minarti, 2011). Perencanaan, pengorganisasian, pelaksanaan dan pengawasan merupakan fungsi dari organisasi yang harus benar-benar bisa dipahami oleh kepala sekolah. Kesuksesan dan kegagalan suatu organisasi, sangat tergantung pada kemampuanya dalam menjalankan fungsi-fungsi manajer secara efektif (Puspitasari, 2015).

Fungsi-fungsi manajemen yang dilakukan oleh kepala sekolah dapat digambarkan sebagai berikut:

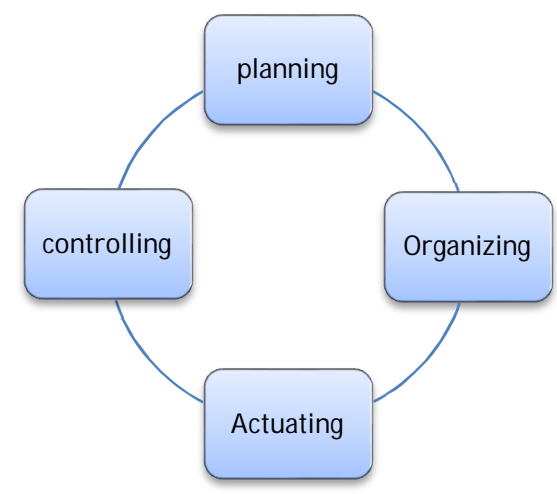

Gambar 1.1: Diagram Manajer (Puspitasari, 2015). 
Berdasarkan gambar diatas maka dapat dijelaskan bahwa peran kepala sekolah sebagai manajer adalah sebagai berikut: (1) perencanaan yaitu proses memilih dan menentukan kebijakan, program dan tujuan dari organisasi; (2) mengorganisasikan yaitu proses pembagian tugas dan wewenang secara terperinci berdasarkan bidang-bidang dan bagian-bagian sehingga tercipta adanya kerjasama yang harmonis; (3) pelaksanaan merupakan tindakan yang dilakukan agar semua anggota kelompok dalam organisasi berusaha untuk mencapai sasaran sesuai dengan yang direncanakan; (4) pengawasan yaitu proses pengamatan untuk mengetahui keefektifan kegiatan dalam organisasi serta untuk mengetahui kelemahan dan kelebihan selama berlangsungnya proses pengelolaan.

Keberadaan kepala sekolah sebagai seorang manajer mempunyai peran yang signifikan dalam rangka mencapai tujuan organisasi (Muhaimin, 2005, Prabowo; 2008; Safitri dkk, 2015).

\section{Budaya Prestasi Sekolah}

Budaya sekolah merupakan ciri khas dari karakter maupun watak yang di bangun dan dianut secara bersama oleh anggota organisasi sebagai moral dalam beradaptasi serta menjadi bagian dari kegiatan dan kehidupan mereka (Mulyadi, 2010) Budaya sekolah akan mempengaruhi suasana kelas, baik kebebasan yang dinikmati peserta didik dalam mengembangkan pikiran dan prestasinya ataupun sebaliknya, budaya yang baik perlu ditanamkan kepada semua komponem yang ada didalam organisasi sekolah agar termotivasi untuk berprestasi.

Budaya prestasi merupakan bentuk budaya sekolah yang mempunyai point utama di setiap sekolah, sehingga mempunyai citra pada masyarakat luas (Yuliono, 2011). Budaya prestasi akan menghasilkan sistem nilai sekolah yang kondusif untuk keberlangsungan dan keberlanjutan dalam berprestasi di sekolah. Budaya prestasi adalah bentuk budaya sekolah yang menghasilkan tatanan nilai yang kondusif serta memiliki point utama yang membedakannya dengan sekolah lain sehingga mempunyai pencitraan pada masyarakat luas (Purnama, 2006).

Penanaman Budaya prestasi sekolah dapat dilakukan melalui: pembinaan nilai-nilai keagamaan, kegiatan orientasi sekolah, proses pembelajaran, evaluasi belajar, ekstrakurikuler, penghargaan prestasi, kecintaan terhadap almamater, keteladanan kepada guru, kerjasama dengan orangtua peserta didik (Yuliono, 2011). Cara efektif dalam meningkatkan budaya prestasi sekolah adalah semua komponen yang ada di sekolah harus memahami pentingnya nilai-nilai dalam kebudayan institusi, agar tercipta tatanan nilai yang kondusif agar termotivasi untuk berprestasi.

\section{Sekolah Efektif dan Sekolah Berprestasi}

Sekolah efektif adalah sekolah yang memiliki manajemen yang baik, transparan dan akuntabel serta mampu memberdayakan semua komponen sekolah untuk mencapai tujuan secara efektif (Anwar, 2011). Sekolah dapat dikatakan efektif jika sekolah dapat mencapai sasaran dan tujuan organisasi, 
yang mana tingkatan pencapaianya ditandai dengan prestasi lulusan sekolah (Marzuki dkk, 2015) sekolah efektif selalu menetapkan keberhasilan pada input, proses, output, dan outcome yang ditandai dengan berkualitasnya komponen-komponen sistem tersebut (Fattah, 2012).

Sekolah efektif akan menghasilkan sekolah yang berprestasi karena mempunyai ketersesuaian yang tinggi antara apa yang telah direncanakan dengan hasil yang dicapai oleh sekolah. motivasi paling penting bagi komponen di sekolah dalam merumuskan perencanaan adalah motivasi berprestasi karena seseorang cenderung berjuang untuk mencapai sukses atau memilih suatu kegiatan yang berorientasi untuk tujuan sukses atau gagal (Yuliono, 2011).

Prestasi sekolah disebut juga dengan keberhasilan sekolah dalam melaksanakan mutu pendidikan. Mutu sekolah dapat dilihat dari sekolah tersebut sudah mendapat akreditasi minimal B (Renstra Kemendikbud, 2015-2019). Menurut (Raihani, 2010) prestasi sekolah dapat dilihat dari prestasi akademik dan non akademik, tingkat kelulusanya tiap tahun dan akreditasi sekolah. Sedangkan menurut (Arifin, 2007) bahwa prestasi sekolah dilihat dari prestasi semua komponen sekolah tersebut.

Prestasi sekolah adalah kemampuan sekolah dalam meningkatkan mutu sekolahnya yang ditunjukkan dengan berbagai prestasi (Mulyasa, 2012).

\section{Ciri-Ciri Sekolah Efektif}

Menurut Pora (2004) sekolah efektif adalah sekolah yang menetapkan keberhasilan sekolahnya sebagai sasaran dan tujuan utama dengan ciri-ciri adanya standar disiplin yang berlaku bagi semua warga sekolah, Memiliki suatu keteraturan dalam rutinitas kegiatan di kelas, mempunyai standar prestasi sekolah yang sangat tinggi, peserta didik mampu mencapai tujuan yang telah direncanakan, peserta didik lulus dengan menguasai pengetahuan akademik, adanya penghargaan bagi siswa yang berprestasi, peserta didik mau bekerja keras dan bertanggung jawab, kepala sekolah mempunyai program inservice, pengawasan, membuat rencana sekolah bersama-sama para guru dan adanya lingkungan yang nyaman bagi para staf. Sedangkan menurut (Mulyadi, 2010) bahwa sekolah efektif adalah sekolah yang memiliki ciri-ciri sebagai berikut: (1) perilaku setiap anggotanya sesuai dengan slogan; (2) para pekerja dilibatkan dalam pemberdayaan; (3) adanya pemberian penghargaan; (4) pendidikan dan pelatihan disediakan bagi para komponen yang ada di sekolah, sehingga mereka memiliki pengetahuan dan keterampilan yang diperlukan untuk perbaikan kualitas secara berkelanjutan.

Inti dari ciri-ciri sekolah efektif yaitu sekolah yang menerapkan kedisiplinan pada semua komponen yang ada, dan perilaku anggotanya sesuai dengan slogan.

\section{Metode Penelitian}

Penelitian ini menggunakan pendekatan kualitatif dengan jenis penelitian deskriptif yang berfungsi memberikan makna secara mendalam 
atas data atau fakta yang ada. Pendekatan ini dipilih karena peneliti mendeskripsikan data, fakta, dan keadaan atau kecenderungan yang ada, serta melakukan analisis terhadap data yang didapatkan.

Data dari penelitian ini adalah mengenai analisis kepemimpinan manajerial kepala sekolah dalam meningkatkan budaya prestasi sekolah di MTSN1 Kota Bima dan MTS Muhammadiyah Kota Bima subyek penelitianya meliputi kepala sekolah, wakil kepala sekolah, komite, guru, kemenag, dan siswa. Pengambilan sampel dalam penelitian ini menggunakan purposive sampling, dari berbagai informan diatas peneliti dapat memperoleh data yang akurat dari hasil wawancara secara mendalam.

Proses analisis data yang dilakukan oleh peneliti adalah melalui tahaptahap sebagai berikut :

1. Reduksi Data

Reduksi data yang dilakukan oleh peneliti yaitumerangkum, memilih hal-hal yang pokok, dan memfokuskan pada hal-hal yang penting yang terkait dengan masalah yang diteliti.

2. Display Data atau Penyajian Data

Penyajian data dilakukan untuk menarik kesimpulan terhadap informasi yang disusun. Bila dalam penyajian data kurang lengkap maka peneliti melakukan pengumpulan data kembali untuk mendukung peneliti.

3. Penarikan kesimpulan

Verifikasi dan validasi data menggunakan teknik triangulasi. Untuk meningkatkan kepercayaan hasil penelitian maka dilakukan pengecekan keabsahan data melalui kredibilitas dengan cara triangulasi sumber dan triangulasi metode.

\section{Pembahasan}

\section{A. Kepemimpinan Manajerial Kepala Sekolah Dalam Meningkatkan Budaya Prestasi Di Kota Bima}

Berdasarkan hasil temuan peneliti menunjukan bahwa dalam melaksanakan tugasnya sebagai manajer ke dua kepala sekolah melakukan perencanaan untuk meningkatkan prestasi akademik dan non akademik siswanya. Selain perencanaan kepala sekolah juga melakukan pengkoordinasian dan kepengawasan dengan memberikan wewenan pada para staf dan gurunya untuk melakukan pembinaan terhadap siswa, dan melaporkanya kepada kepala sekolah terkait perkembangan hasil belajar siswa yang dibina. Perbedaan antara kedua kepala sekolah dalam melakukan pembinaan yaitu. MTS Muhamamadiyah melakukan pembinaan terhadap siswanya ketika akan mengikuti lomba sementara MTSN I Kota Bima diadakan pembinaan setiap minggu.

Peran kepala sekolah sebagai manejer di sekolah sangat penting karena dalam tindakanya akan mempengaruhi komponen yang ada di sekolah untuk bekerja lebih giat dalam mencapai tujuan. Hal ini sama dengan hasil penelitian yang juga dilakukan oleh Suyitno (2017) tentang strategi kepala Sekolah dalam peningkatan prestasi belajar siswa (studi kasus di SMPN 1 Fakfak) menunjukan bahwa peran kepala sekolah sebagai manejer 
yaitu kepala sekolah mampu menggerakkan bawahannya (guru, dan staf sekolah) dalam upaya meningkatkan mutu pendidikan sebagai wujud pengelolaan pendidikan. Berorientasi pada prestasi belajar siswa dengan berbagai hal sebagai berikut: (1) Program Kerja yang direncanakan, (2) Mengirim Guru untuk workshop, penataran atau diklat.

\section{B. Faktor Pendukung Keberhasilan Kepala Sekolah MTSN I dan MTS Muhammadiyah Kota Bima Sebagai Manajerial Dalam Meningkatkan Prestasi Di Sekolah.}

Berdasarkan hasil temuan peneliti menunjukan bahwa ada beberapa hal yang menentukan keberhasilan kepala sekolah sebagai manajer di MTSN I kota bima diantaranya: (1) adanya dukungan dari orang tua siswa atau komite: (2) adanya dukungan dari kemenag; (3) rasa ingin tau siswa sangat tinggi hal ini terlihat dari keaktifan mereka di kelas pada saat kegiatan belajar mengajar berlangsung, dan aktif mengikuti kegiatan lomba-lomba: (4) adanya kebersamaan kepala sekolah, guru dan staf dalam mengoptimalkan potensi yang dimiliki siswa. Sementara faktor pendukung keberhasilan MTS Muhammadiyah yaitu kebersamaan dan keikhlasan dalam mengajar dan membimbing siswa agar bisa berprestasi, Kebersamaanya diaktualisasikan dalam bentuk arisan bersama dengan tenaga pendidik dan kependidikan. Hal ini senada dengan hasil penelitian yang dilakukan oleh Suyitno (2017) menyatakan bahwa keberhasilan program-program sekolah atau Madrasah ditentukan oleh starategi yang tepat untuk memberdayakan tenaga pendidik dan kependidikan melalui kerja sama kooperatif, memberikan kesempatan kepada pendidik untuk mengembangkan profesinya, membangun strategi yang tepat untuk menjalin hubungan yang harmonis dan menanamkan sikap disiplin dalam bekerja.

Hasil penelitian juga menunjukkan bahwa peningkatan prestasi di sekolah dikarenakan adanya persiapan khusus yang dilakukan oleh sekolah dalam membimbing siswa. The club (kelompok belajar), kelompok ini dibuat khusus untuk anak-anak yang memiliki bakat dan minat yang sama pada kegiatan kurikuler dan ekstrakurikuler. Menurut (Mulyasa, 2011) dengan adanya penyaluran bakat dan minat siswa menunjukan bahwa sekolah tersebut sudah memberikan layanan terbaik kepada siswanya.

\section{Faktor Penghambat Kepala Sekolah Sebagai Manajerial Dalam Meningkatkan Prestasi Di Sekolah}

Berdasarkan hasil temuan peneliti di lapangan bahwa tidak ada kendala yang berarti yang dihadapi oleh sekolah dalam meningkatkan prestasinya karena semua komponen yang ada di sekolah sudah tau tugas dan tanggung jawabnya masing-masing. Hanya saja guru-guru kurang semangat dalam membimbing siswanya dikarenakan jadwal yang dinilai kurang efektif bagi para guru-guru, karena mereka harus datanng lagi ke sekolah. Sementara faktor penghambat kepala sekolah MTS Muhammadiyah kota bima dalam meningkatkan budaya prestasi di sekolah sebagai berikut: (1) pendanaan yang terbatas; ; (2) fasilitas yang serba terbatas; (3) guruguru yang sering tidak hadir; (4) tidak ada dukungan dari masyarakat. Akibat 
pendanaan yang serba terbatas maka pembinaan untuk kegiatan akademik dan non akademik hanya dilakukan ketika akan mengikuti lomba, dalam mengelola sekolah atau organisasi pasti ada saja permasalahan yang terjadi. Hal ini senada dengan hasil penelitian yang di lakukan oleh Wijayanti \& Karwanto (2010) tentang analisis kepemimpinan kepala sekolah dalam meningkatkan prestasi di sekolah, menunjukan bahwa masalah yang menghambat peningkatan prestasi di sekolah, bersumber dari kurangnya dukungan dari orang tua siswa dan biaya.

\section{Upaya Kepala Sekolah Sebagai Manajerial Dalam Menghadapi kendala Meningkatkan Budaya Prestasi Di Sekolah}

Upaya yang dilakukan oleh kepala sekolah MTSN 1 kota Bima dalam menghadapi kendala untuk meningkatkan prestasi di sekolah adalah memberikan motivasi kepada para staf dan siswa untuk menaati peraturan dan kedisiplinan, serta memberikan pengertian akan pentingnya pembinaan terhadap siswa. Sementara upaya kepala sekolah MTS Muhammadiyah dalam menghadapi kendala antara lain: memberikan motivasi kepada para staf dan juga para siswa untuk menaati peraturan. Sedangkan untuk kendala eksternal kepala sekolah meminta bantua sarana dan prasarana di kemenang berupa memasukan proposal. Hasil penelitian menunjukan bahwa kepala sekolah telah berusaha semaksimal mungkin untuk bisa mengatasi berbagai persoalan yang ada di sekolahnya. Hal ini senada dengan hasil penelitian yang dilakukan oleh (Marsongko, 2009) bahwa untuk mengatasi berbagai kendala kepala sekolah mengadakan koordinasi dengan stakeholder yang ada, mengadakan bimbingan, pelatihan, diklat dan supervisi.

\section{Kesimpulan}

Berdasarkan hasil penelitian mengenai kepemimpinan manajerial kepala sekolah dalam meningkatkan budaya prestasi di MTSN I Kota Bima dan MTS Muhammadiyah Kota Bima maka diperoleh kesimpulan sebagai berikut: (1) untuk meningkatkan prestasi di sekolah yang dipimpinya, kepala sekolah MTSN I Kota Bima menugaskan guru-guru khusus untuk melakukan pembinaan kepada siswa setiap minggunya. Guru-guru ini dipilih berdasarkan kecakapan yang mereka miliki; (2) prestasi yang diraih oleh siswa MTSN I Kota Bima di berbagai ajang olympiade didapatkan, karena adanya pembinaan secara intensif setiap Minggunya; (3) adanya dukungan semua pihak seperti: guru, wakil kepala sekolah, komite, kemenag, dan orang tua wali murid memberikan pengaruh yang besar bagi peningkatan prestasi di sekolah MTSN I Kota Bima; (4) kendala pada kepemimpinan kepala sekolah MTSN I sebagai manajerial yaitu kurang Semangat guru-guru dalam melakukan pembinaan terhadap siswa, namun permasalahan ini bisa di atasi karena kepala sekolah sangat loyal dalam mendengarkan aspirasi bawahanya.

Kepemimpinan manajerial kepala sekolah MTS Muhammadiyah di peroleh kesimpulan yaitu: (1) pembinaan terhadap siswa hanya dilakukan jika mengikuti lomba hal ini menyebabkan prestasi di sekolah menurun; (2) prestasi yang didapatkan sekolah kurang, karena kurangnya dukungan dari 
semua pihak; (3) kendala yang dihadapi oleh sekolah dalam meningkatkan prestasi yaitu kurang disiplinya guru-guru, belum memadainya sarana dan prasarana, dan pengelolaan sekolah yang dilakukan oleh kepala sekolah tidak sesuai dengan rencana yang telah ditetapkan. 


\section{Daftar Rujukan}

Anwar, Qomari. 2011. Sekolah yang Efektif. , diakses tanggal 19 desember 2016.

(Online),(http:// ngatimin.weebly.com/ uploads/5/4/1/1/5411453/ se kolah efektif.ppt

Andang, 2014. Manajemen dan Kepemimpinan Kepala Sekolah, Yogyakarta: AR-Ruzz Media.

Arifin. N. (2007). Strategi Kepala Sekolah Dalam Mencapai Prestasi, Jogjakarta: Adityah Media.

Biro Hukum dan Organisasi Departemen Pendidikan Nasional: Kepala Bagian Penyusunan Rancangan Peraturan Perundang-undangan dan Bantuan Hukum I: Peraturan Menteri Pendidikan Nasional Republik Indonesia Nomor 13 Tahun 2007 tanggal 17 April 2007 Tentang Standar Kepala Sekolah/ Madrasah.

Dally, Dadang. 2010. Balanced scorecard suatu pendekatan dalam implementasi berbasis sekolah, Bandung: Rosdakarya

Fattah, N. 2012. Manajemen Berbasis Sekolah, jakarta: Universitas Terbuka.

Harjosoedarma, S. 2004. Total Quality Management, Yogyakarta: Andi

Marzuki, dkk. 2015. Pengembangan Budaya Dan Iklim Sekolah Di SMA NEGERI

2 Bandar Lampung (Jurnal) diakses tanggal 4 desember 2016 http:/ / download.portalgaruda.org/ article.php?article=254147\&val=6 $\underline{848 \&}$

Marsongko MJ Hari, (2009). Kepemimpinan Kepala Sekolah dalam Meningkatkan Mutu Pendidikan Sekolah. Studi Kasus Tentang Manajemen Kepala Sekolah Di Sd Muhammadiyah Wonorejo Polokarto (tesis). Diakses 1 desember 2016 dari https:// digilib.uns.ac.id

Minarti, Sri. 2012. Manajemen Sekolah Mengelolah Lembaga Pendidikan Secara Mandiri, Jogjakarta: Ar-ruzz Media

Mulyasa. E. 2003. Pedoman Manajemen Berbasis Madrasah, Jakarta: Depag.RI.

Mulyasa. E. 2007. Menjadi Kepala Sekolah Profesional, Bandung: PT Remaja Rosdakarya

Mulyasa, E. 2011. Standar Kompetensi Dan Sertifikasi Guru. Jakarta: Bumi Aksara.

Mulyasa, E. 2012. Manajemen Dan Kepemimpinan Kepala Sekolah, Jakarta: Bumi Aksara

Mulyadi. 2010. Kepemimpinan Kepala Sekolah Dalam Mengembangkan Budaya Mutu, Malang: UIN. Maliki Press

Muhaimin, 2015. Manajemen Penjaminan Mutu Di Uneversitas Islam Negeri Malang, Malang: Tp. UIN maliki. Press

Munir, Abdullah. 2008. Menjadi kepala sekolah efektif, Jogjakarta: AR-Ruzz Media

Prabowo, Sugeng listiyo. (2008). Penjaminan Mutu Dengan Sistem Manajemen Mutu Iso 9001 :2000 Diperguruan Tinggi Studi Multi Situs Pada Stiemalangkucecwara Malang Dan Universitas Narotama Surabaya (disertasi). Universitas Negri Malang. 
Peraturan Mentri Pendidikan Dan Kebudayaan Republik Indonesia No 23 Tahun 2013 Tentang Perubahan Peraturan Meteri Pendidikan Nasional No 15 Tahun 2010 Tentang Standar Pelayanan Minimal Pendidikan Kabupaten/ Kota

Peraturan Menteri Pendidikan Nasional No 63 Tahun 2009 Tentang Sistem Penjaminan Mutu

Permendiknas No 28 Tahun 2010 Tentang Penugasan Guru Sebagai Kepala Sekolah/ Madrasah

Permendiknas No 13 Tahun 2007 Tentang Standar Kepala Sekolah/ Madrasah

Pora, Yusran. 2004. Selamat Tinggal Sekolah, Yogyakarta: Media Pressindo

Purnama, Nursa'bani. 2006. Manajemen Kualitas Perspektif Global, Yogyakarta: PT. Ekonosia

Puspitasari, Norma (2015). Kemampuan Manajerial Kepala Sekolah Dalam Meningkatkan Kinerja Guru Studi Kasus SMK Batik I Surakarta (Tesis) ISSN:2442-7942 volume I. No 1. di akses I Desember 2016 http:// www.poltekindonusa.ac.id/ wp-content/ uploads/ 2015

Rahman ,at.al 2006. Peran Strategi Kepala Sekolah Dalam Meningkatkan Mutu Pendidikan, Jatinangor: Algaprint

Raihani, 2008. Kepemimpinan kepala sekolah transformatif, yogyakarta:PT. LKIS. Printing Cemerlang

Renstra kemendibud 2015-2019 diakses 1 desember 2016 dari http:// pendis.kemenag.go.id/index.php?a=artikel\&id2=strategipendis \#.WEjupdKLTIU

Safitri, Elda dkk (2015) Kemampuan Manajerial Kepala Sekolah Dalam Meningkatkan Kinerja Guru Di MIN Ruko Banda Aceh Jurnal Administrasi ISSN 2302-0156 Volume 3 No 4 November 2015 Diakses Tanggal2Desember2016http:// www.jurnal.unsyiah.ac.id/JAP/ article/ view/ 5678

Saondi, Ondi (2014). Membangun Manajemen Pendidikan, Bandung: PT. Reflika Aditama

Siagian, Sondang P. 2003. Teori dan praktek kepemimpinan, Jakarta: Rineke Cipta

Subandono, Heru (2011). Kepemimpinan kepala sekolah dalam membentuk motivasi kerja guru studi kasus tentang manajemen disekolah mesjid terminal depok propinsi jawa barat. (tesis). Diakses I desember 2016 http:// repository.upi.edu/ 9353/2/t pmp 0909552

Sugiyono. 2012. Metode Penelitian Kuantitatif Kualitatif dan R \& D, Bandung : Alfabeta

Suyitno, 2017. Strategi Kepala Sekolah Dalam Peningkatan Prestasi Belajar Siswa (Studi Kasus Di Smpn 1 Fakfak. Jurnal. Konstruktivisme, Vol. 9, No. 1, januari 2017 diakes 18 desember 2017 http:/ / konstruktivisme . unisbablitar. ejournal.

Tilaar. H.A.R. 2007. Manajemen Pendidikan Nasional, Bandung: Remaja.Rosdakarya. 
Undang-Undang Republik Indonesia No 20 Tahun 2003 Tentang Sistem Pendidikan Nasional

Usaid-Kinerja , 2014.Tata Kelola Penerapan Standar Pelayanan Minimal (Spm)

Bidang Pendidikan Dasar Untuk Kabupaten/Kota(Online) Di Akses 13 September http:// www.kinerja.or.id.

Wahjosumidjo, 2002. Kepemimpinan Kepala Sekolah, Jakarta : Grafindo Persada

Werang, Basilus. R. (2012). Hubungan Keterampilan Manajerial Kepala Sekolah, Iklim Sekolah, Dan Moral Kerja Guru Dengan Kinerja Guru di SMA Negeri Kota Merauke . Jurnal Aplikasi Manajemen. Volume 10, No 3, September 2012 di Akses Tanggal 1 Desember 2016 http:// download.portalgaruda.org/ article.php?article $=254147 \& v a l=6$ $\underline{848 \&}$

Wijayanti, Indra Dwi \& Karwanto.(2010) Kepemimpinan Kepala Sekolah Dalam Meningkatkan Prestasi Sekolah Studi Kasus Di SMP PGRI 6 Surabaya Jurnal. universitas Negeri Surabaya Diakses 1 desember 2016 dari https:// digilib.uns.ac.id

Yuliono, Agus (2011). Pengembangan Budaya Sekolah Berprestasi Tentang Penanaman Nilai Dan Etos Berprestasi Di Sma Karangturi Jurnal Komunitas Volume 3, No 2, September 2011 di Akses Tanggal 2 Desember 2016 http://journal.unnes.ac.id/nju/index.php/komunitas 